\title{
Time to tweet
}

\section{Ecologist Gaston Small uses social media to talk about his work. Others, he says, must join him.}

을 The call to arms came one morning in early February, as I was listening to a well known science journalist speak during a panel discussion on sustainability at Arizona State University in Tempe. "Science journalists are an endangered species," he said. Given the decline of traditional media in recent years, this didn't exactly come as a surprise, yet the implications resonated with me. Science journalists have been the bridge linking the sometimes opaque world of scientific research to the arena of public discourse. If they disappear, must scientists fill the void?

Many of us can name a handful of scientists who are very effective at communicating with the general public and with policy-makers, but they are exceptions. Science is hard work in itself, and communicating with an audience of non-scientists requires a skill set and a perspective that are wholly different from those on which we rely in our daily interactions with scientific colleagues.

A way to take a tentative step towards gaining those skills, suggested some colleagues at the conference, is to embrace new media and, specifically, to start posting on Twitter. I must confess that I can be a bit slow to adopt new technology. My seven-year-old mobile phone does little more than send and receive calls - although I take comfort in the fact that I might still be smarter than my phone, at least until I am forced to upgrade. I had actually joined Twitter several months before the panel discussion, after hearing about the clever posts of a colleague (which, ironically, led to the conference in question). But I had not got as far as uploading a profile picture or posting my first tweet.

When I logged in that night, for the second time ever, I was shocked to learn that I had four 'followers'. Instantly, I felt obliged to provide this audience with a steady diet of wit and timely information. This newfound responsibility was quickly followed by insecurity I'm not sure that I have a surplus of insight to dispense to the world several times a day.

As I sat at the desk in my hotel room, midnight approaching, Twitter's empty text box filled my laptop monitor. Assembling 140 characters to convey a pithy message suddenly seemed more daunting than writing a 140-page dissertation. After several false starts, I settled on my first post: "Two days spent thinking about the human food

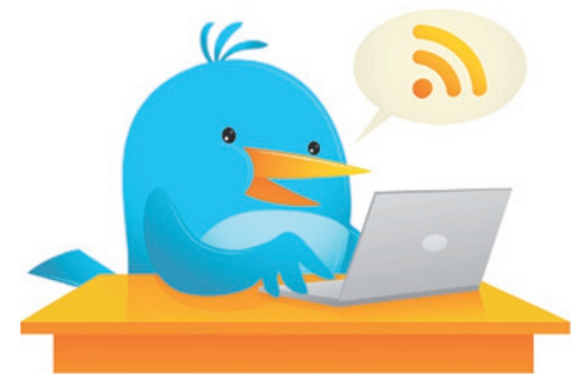

chain. Fittingly, Oscar Meyer Weiner-mobile [sic] is parked in front of our hotel." As I clicked 'submit', I wondered whether I had achieved the balance of irony and insight appropriate to the world of new media. And what opportunities had I wasted with those 12 unused characters?

After several months of posting the occasional tweet about my work, I harbour no illusions that my twitterings will fill the void created by the loss of professional science journalists. However, judging from the list of my followers, I am sharing scientific ideas with a broad (if small) audience.

The real value of social media for scientists (aside from teaching us to communicate concisely) may be that we are forced to think about how to share ideas with a broader audience, one that ultimately pays for most of our research: taxpayers. Public conversations about our research make scientists accountable for delivering something of value to those taxpayers. In an era of budget cutting, early-career scientists will have to be effective ambassadors for the profession. This might manifest in conversations with family members or with strangers sitting next to us on a plane, or it might mean posting videos on YouTube or blogging about our ongoing research. The days of scientists communicating only with each other, in the languages of our individual disciplines, and relying on science journalists to translate for the public, are rapidly coming to an end. You probably won't find me on the cutting edge of science communication, but maybe I won't be left completely behind. Judge for yourself by following me, @chip_small, on Twitter as I elucidate my own research, 140 characters at a time.

Gaston Small is a postdoc in ecology at the University of Minnesota in St Paul.

\section{COLLABORATION}

\section{Europe-China deal}

A reciprocal agreement between the European Union (EU) and China will help researchers to spend time in each area. The deal will lift barriers such as restrictive visa conditions and will improve recognition of qualifications, says European Commission (EC) spokesman Dennis Abbott. Researchers from both areas will be funded by the EC's Marie Curie Actions; the programme is seeking a $50 \%$ budget increase in its next round of funding, beginning in 2014 , to a total of nearly $€ 7$ billion (US\$9.7 billion), says Abbott. The amount will be confirmed on 30 November. Since 2007, some 550 Chinese researchers have received Actions grants to work in Europe, but far fewer EU researchers have gone to China.

\section{RESEARCH OUTPUT}

\section{Britain holds its own}

The United Kingdom was second only to the United States in terms of total scientific-paper citations last year, says a report prepared for the UK Department of Business, Innovation and Skills. International Comparative Performance of the UK Research Base - 2011, released in October by publishing company Elsevier in Amsterdam, finds that in 2010, UK papers had 3.46 million citations; those from the United States had 13.2 million. Britain also outperforms all nations for articles produced per unit of research spending. Meanwhile, Brazil, Russia, India and China have increased their share of the world's published science papers. China's share climbed from about $12 \%$ in 2006 to just over $17 \%$ in 2010 , the report says.

\section{EMPLOYMENT}

\section{Scientists leave research}

University graduates with skills in science, technology, engineering and maths (STEM) are in high demand in nonSTEM jobs in the United States, says a report, STEM, released on 20 October by Georgetown University in Washington DC. STEM graduates often work in health care and in managerial and professional jobs in sales or manufacturing. Co-author Nicole Smith, a Georgetown economist, says that non-STEM posts pay better than academia, which is a big draw. Women preferred non-STEM posts that offered flexibility and promotion. The report, which used data from about 20,000 graduates, says STEM departments should help university students to find work in their areas of study. 